JAPANESE JOURNAL OF INFLAMMATION

EDITORIAL

\title{
We should do works which remain in the history of medicine
}

Ryuichi Kato

\section{歴史に残る研究をしよう}

\section{加 藤 隆 - $^{*}$}

最近, 多くの若い人が熱心に研究をして招り, 日本の医学・生物学の将来にきわめて頼 もしいかぎりである。これら若い人に，

「なぜ君たちはそんなに熱心に研究をやっているのか」

と問うと，

「研究が物もしろいからやっている」

といら応觉が返ってくることが多い.

確かに招もしろいことが研究にとって一番大切なことである。ただ，もし，それらの研 究がほとんど引用されずに， 2,3 年後には消えてしまったら，若い膨大なェネルギーと， 時間と，扣金を掛けたそれらの研究は，きわめて虚しいものになろう。

オリンピックには参加することに意義があるとよくいわれるが，やはり勝つことが肝要 であろう．大学などには，先端のサイエンスの研究に参加していることに自己満足してい る若い研究者もかなり多く見られる。

現在の科学の進歩はきわめて速く，激しい競走（競争ではない!）が日々行われて拉 り, 特に遺伝子クローニングに関しては 1 等賞はあるが， 2 等賞はないとされている（他 の分野では 2 等賞も 3 等賞もあったのではあるが……).

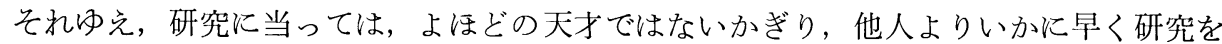
開始するか，他人よりいかに効率よく研究を行らか，研究要員をどれだけ投入するか，い かに上手に論文をまとめるか，などが勝敗の決め手となることが多い．半年でも 1 カ月で も早く論文をだし，それが消されないように継続的によい仕事をしていく以外に凡人が歴 史に生き残る道はない。

炎症に関する研究も10年前とは異なり，それらに関与する諸因子が見いだされ，それら の相互作用，または細胞の置かれているマトリックスなどの環境因子は，役割も重要視さ れてきている。しかし，現在の細胞・組織培養の技術，物質の精製の技術，遺伝子クロ一 ニングの技術の進歩により，種々の生理活性物質の分離・同定・生産が以前にくらべて格 段と容易になり，炎症に関する現象を，それらの物質をin vitro 扣よび in vivo で追えるよ らな時代になってきたといえよう。これら新規因子の分離・構造決定・生理作用解明の仕 事は若い研究者が歴史に残る研究として行光るもっとも輝かしいものであろう.

in vitro の系で明らかにされたこれらの因子の生理機能が，他の細胞の存在下，組織内で いかに発現され，ぞのように役割を演じているかが明らかにされてこそ，その制御機構も 明らかになり，それらを促進したり制御する薬も開発されるであろら。

炎症に関する分子レベルでの研究ははじまったばかりであるが，近い将来には免疫・炎

* Department of Pharmacology, School of Medicine, Keio University 慶応大学医学部薬理学教室 
症薬理学として薬理学の最重要テーマの一つになるであろらし，中・長期の経過に括ける 生体の反応・防御機構の中心の課題として免疫・病理学の重要テーマとなろう。それには 分子レベルから細胞, 組織, 個体レベルでの研究の発展が必要であろら。さらに新しい生 理活性物質の作用機序に基づく, 新しい薬も創製され, 診断, 治療法などの発達とともに 新しい病因機序も解明され, 炎症に関する研究は医学のみならず, quality of life の中心 課題に発展していく日もくるであろう.

若い優秀な研究者が，短時間の生体の応答機構に興味を持つばかりではなく, 炎症とい う複雑な機構を, それらに関与する生理活性物質の解明といら観点からチャレンジして, 歴史に残る仕事をすることを念願したい. 